\title{
ANIKÓ SÁNDOR
}

\section{Self-determination Opportunities of Persons with High Support Needs}

\section{INTRODUCTION}

Based on the theoretical framework of Critical Disability Studies, the paper presents the characteristics of self-determination of persons with high support needs in different types of living arrangements in Hungary. The research design is based on a qualitative and participatory approach (according to this, the text was consciously formulated in first person plural) and the study was conducted as the doctoral work of the author.

The key starting point is that Hungary ratified the UN Convention on the Rights of Persons with Disabilities in 2007 (hereafter referred to as CRPD). The CRPD states that States Parties shall recognize the importance of individual autonomy, independence and choice-making [in particular: Preamble n), Article 3, Article 12]. Article 12 of the CRPD on Equal recognition before the law can only be interpreted in the light of Article 19 on Living independently and being included in the community. Gerard Quinn defines Article 19 as a window to Article 12 and Article 12 as an anchor of Article 19 (Quinn, 2013), so we conducted the research in the context of different living arrangements. Instead of independence, self-reliance or self-sufficiency, selfdetermination as a social and cultural concept can be a framework that is suitable for approaching the life situations of people with high support needs.

Persons with high support needs can be characterized as the most neglected and vulnerable group of people with disabilities. During the course of history, they were the first people who needed nursing, but did not need education. Then they became lives unworthy of life, whose killing is not punishable because they cannot be considered as human beings (Evans, 2010). Later on, they joined the educational system in Western societies, but they are still the ones who are often denied the services they need. It can be noticed that nowadays, society excludes them from the system of disability support services (Fornefeld, 2008; Dederich, 2008; Zászkaliczky, 2014). They experience oppression, such as marginalization, powerlessness and violence in their everyday life (Young, 1990). Therefore, when we talk about them, at the same time we raise the question of lower support needs, age, childhood, illness, ethnic groups and solidarity, that are fundamental issues affecting each and every member of society. Persons with high support needs expose elements of self-determination that would otherwise be hidden as we automatically fulfill the expectations that society latently imposes on us. 
People with intellectual disabilities who are capable of self-reporting consider their self-determination to be significantly more important than their parents and teachers, while assistants believe that the question of self-determination is irrelevant in the lives of persons with such disabilities (Wehmeyer et al., 2000; Schalock et al., 2005; Martin et al., 2005). As Wehmeyer suggests, this idea can be derived from a misinterpretation of the construct of self-determination (Wehmeyer, 2005), and it is believed that the misinterpretations originate from the assistants' concepts of human, their understanding of what disability is, and their interpretation of their own role (Weingärtner, 2009; Theunissen, 2012; Emerson et al., 1994; Hellzen et al., 2004; Bigby et al., 2009; Walker et al., 2011). The topic is relevant because tens of thousands of persons are involved, who in general face numerous disadvantages in their everyday lives. There have been some case studies in Hungary that focused on this issue (Galambos et al., 2003), and the self-determination paradigm has been a part of scholarly discourse since the 1990s (Zászkaliczky, 1998). It is well known that the people living in institutions are mostly under guardianship and face significant limitations in autonomous decision making (Kozma, 2008; Verdes, 2009). However, in the first decade of the 2000s, Hungarian empirical research on the quality of life of the group was based more on a quantitative approach, and examined the life situation of families and the services available to them. It has been shown that families who raise children with high support needs, cannot maintain their former social and economic status, and they live in poverty and have a lack of social networks. Bass and Márkus have pointed out that due to the above factors the families do not have enough resources, which would allow for self-determination and advocacy, so it was necessary to explore the deeper layers of these issues through qualitative research (Bass, 2004; Márkus, 2005).

\section{RESEARCH QUESTIONS}

The main research question is: what kind of support is available today for persons with high support needs in Hungary to ensure self-determination in different areas of life that are relevant to them?

\section{Further questions:}

How do assistants support persons with high support needs in their selfdetermination?

What are the characteristics of self-determination of persons with high support needs in different living arrangements?

What characterizes the assistants' notion of what being human means and how do they interpret their own role?

How can the community of a group home be supported to extend options for selfdetermination for persons with high support needs? 


\section{Methodological baCkground}

Investigating self-determination is a major challenge in the case of people with high support needs. On the one hand, it can be questioned if self-determination is a measurable phenomenon (Haeberlin, 1996). On the other hand, the use of selfreport-based indicators is not possible (Wehmeyer, 2005; Seifert, 2006). Thus, we applied a qualitative approach suitable for involving persons who typically communicated nonverbally, and we supplemented that information with the views of their trusted assistants. The Grounded Theory approach had the most important impact on our research (Glaser \& Strauss, 2006; Corbin \& Strauss, 2015).

We conducted participant observations within the qualitative paradigm, as well as focus groups and individual interviews, and prepared minutes and transcripts. The transcriptions were analyzed using the Mayring qualitative content analysis technique (Mayring 2015; Mayring \& Gläser-Zikuda, 2008).

Our work is based on the participatory paradigm, with the aim to learn about the possibilities and limitations of inclusive research with persons with high support needs. Participation could be realised in small elements of the research process, mainly through an advocatory role. In the research, a person with high support needs, Richárd Zachareszku, took part from the planning to the analysis of the four-year research period. We met three to four times a month, and through our relationship, he influenced all observation situations and interviews.

The whole process of the research was accompanied by a reflective, nonstandardized research diary, which included all relevant events, research reflections and self-reflections. The research diary is a tool of qualitative field research, which supports the analysis of the process and the methods used (Weigand, 2009; Friebertshäuser \& Panagiotopoulou, 1997; Barnes, 1992, 1996; Fischer \& Bosse, 1997).

The sample selection did not aspire to be representative, but rather, it wanted to ensure that the typical life situations of persons with high support needs are represented: one group lives in a small or large residential institution (in a group home or a residential home with more than 10-12 persons), the others live with their parents or siblings. In addition to the disabled persons, we also addressed close support persons (relatives, caregivers, educators, etc.). After weighing the results of the literature review, we did not use diagnostic tools based on the support needs and did not use available medical, special educational and psychological diagnoses. Following Beamer and Brookes and Seifert's sample selection criteria, we added our own criteria and worked with persons with high support needs, who:

- do not speak or speech is not their primary communication channel,

- live with intellectual disabilities, which in many cases are associated with physical disability or illnesses,

- have other labels such as "problematic behavior",

- require intensive support in their daily lives in all areas (Beamer \& Brookes, 2001; Seifert, 2006); and

- are considered to belong to the group according to their environment.

In the first phase of the research, which lasted from January 2014 to June 2015, we included two group homes belonging to the same NGO. The selection was based 
on nonprobability sampling. We chose institutions where people with high support needs lived.

The observation directly involved 7 persons living in the group homes. We conducted semi-structured interviews with 6 of their relatives or guardians. The support staff in the group homes participated in focus group interviews. Semistructured interviews and focus groups were recorded at the beginning and at the end of the process, and the observations took place in the middle and at the end of the process. During the process, some of the participants died and some of them left their workplace, making it difficult to pinpoint the exact sample of this research phase. However, this was considered as the normal feature of the field and was supported by the continuous reconsideration of the methods used. The research design also included the participation in the team meetings and an internal, Disability Studiesbased employee training organized at the end of the process.

The interviewees involved in the second phase of the research were mainly reached through institutions. We did not differentiate between the employees of the institutions in terms of their qualifications, but we included professionals and untrained persons as well, who perform some kind of occupational support, nursing or who serve as heads of these institutions. Interviews were conducted in small group homes providing services for 10-12 persons and supported living providers (5 interviews) and the staff of residential institutions providing services for 12 to 200 people (17 interviews). The gender ratio is determined by the field: at this stage, there was one male interviewee who had a leading position in one of the large residential institutions.

Besides the interviews with the staff, interviews were also made with relatives. We reached the persons still living with their families through the day-care system. With this technique, families who did not use services could not have access to this study. 6 interviews were conducted with parents or siblings of persons who live in their families of origin and 6 interviews were conducted with family members whose adult relatives are already living in one of the institutions.

The interviewees, also taking into account day-care services, were connected to 8 different institutions, some of which belong to a common service provider. One of the group homes was created specifically for persons with high support needs within the large institution itself. Some of the living arrangements operate in large cities, others operate in small towns or villages. To ensure that institutions and participants remain anonymous, we do not disclose any specific information about the size or location of the facilities.

\section{RESULTS AND CONCLUSIONS}

Our study has shown that some elements of self-determination can be observed in all forms of living arrangements. These elements are typically part of the everyday routine and are connected to fulfilling basic human needs.

It is extremely difficult for participants in the research to translate the meaning of self-determination into everyday situations. The concept is used actively and consciously by very few people, so it has little influence on the support as well. The misinterpretation of self-determination is the key obstacle in the process of support. 
Self-reliance, decision-making, self-advocacy are aims that can hardly be interpreted in the case of persons with high support needs. That is why assistants think that self-determination is unavailable to this group and is not a relevant and meaningful principle.

All sections of the research confirmed that for persons with high support needs the self-reliance and possibility of choices in eating, listening to music and playing are the most important areas of self-determination. It affirms the theory of basal self-determination (Weingärtner, 2009) that these areas are linked to the everyday, most basic human experiences and provide opportunities for creating choice-making situations. Although at different levels, but in all types of living arrangements, these situations have emerged, or at least they were not hindered. The latter addition is important because effective support could only be provided if the creation and strengthening of these situations would have been the result of conscious, coordinated professional activity. However, the persons with disabilities have little or no opportunity to experience their own influence and to experience the consequences of their activities.

The practice of promoting self-determination is clearly influenced by the level of support needs. Most assistants say there is a kind of "border" in the field of communication and cognitive skills beyond which the concept of self-determination cannot be interpreted. Persons with lower support needs have broader selfdetermination options in every kind of living arrangement. Differences are reinforced by a variety of routines, such as categorisations and different labels for different support needs. Persons who cannot move are more likely to experience their vulnerability because physical barriers require their support to involve more resources. In that sense, they have less chance of self-determination. At the same time, with the lower level of self-determination, they are those who experience fewer restrictions because they cannot actively cause situations that are considered to be disturbing. In our analysis, we have come to the conclusion that this relationship may be subject to further research in the future, as it may help to develop alternatives to restrictive measures and relieve assistants. The level of support needs is not the only influencing factor. Self-determination is created in the dynamic interactions between the individual and the assistants. It is determined by the subjective significance and the desired level of self-determination, and the possibility of exercising it.

Assistants, regardless of whether they are family members or paid assistants, are involved in systemic oppressive power mechanisms. They are experiencing serious constraints in their work and do not have a voice in organizing and managing services. Therefore, they also prefer protection and continuous supervision and control over the activities of persons with disabilities.

We can conclude that the larger institutions are most likely to be characterized by the emphasis on the infant-status of adults with high support needs and the use of the very serious restrictive measures resulting from this attitude. Four groups were defined based on the observed restrictions, which are located along an interval. On one end of this continuum, there are severe physical restrictions, while on the other, there are useful, constructive social expectations. Small institutions and families are more prone to construct these positively-assessed, constructive expectations that are in accordance with our culture. In all arrangements, however, it is difficult to 
maintain a balance between self-determination and restrictions on behalf of physical needs and emergency situations.

However, in this study, we cannot support the assumption that the restriction would be strongest in the family of origin, in the presence of parents or siblings. In this context, the social interpretation of self-determination and the importance of participation are the most common values. Families live together, mainly because of the lack of acceptable alternatives and the operational anomalies of existing services, not because they want to limit their children. However, it can be seen that even families, which support higher levels of empowerment find it difficult to organize social participation, programs, and they live more or less isolated. From this point of view, larger institutions are in a better position because they can use more resources to mobilize disabled people. However, persons with the highest support needs, especially those using tubes or wheelchairs, are often excluded from these recreational opportunities.

Types of living arrangements clearly influence how hierarchy develops and at the same time, the risk of power abuse in certain situations is inevitable. Experience confirms that this phenomenon is most noticeable in large institutions. In organizations where the number of employees sometimes exceeds 100 people, it is inevitable that this will develop and this will make it impossible to provide support for selfdetermination. Although small service providers (group homes and supported living) have been treated as one category, it can be observed that there is a difference between their operations. The most direct contact between the persons with disabilities, the workers and the relatives could be found in the non-governmental organizations providing supported living.

In institutions, the principle of self-determination is most desired by the management, while assistants believe that it is an unrealistic goal. In addition to the way they interpret their own role, this can be explained by environmental conditions. As long as there are service providers who respond to the lack of workforce by requiring restrictions on fulfilling basic needs (e.g. no need to bathe at weekends, workers buy their own nursing equipment, etc.), it is difficult to interpret the need for self-determination in relation to any actors involved. In smaller living arrangements, with more direct relationships, employees have more power to influence processes and are therefore more satisfied and more supportive.

The support staff working in institutions mostly interpret their role based on four pillars: education, protection, supervision and control. They believe that they work in the interests of persons with disabilities if they help them to accommodate themselves to institutional culture and keep them under constant control, thus preventing accidents or emergencies. In most cases this happens routinely, not consciously, and is not accompanied by professional reflection. In group homes and supported living, role interpretations are more in the direction of equality and partnership. The providers and users of these services have reported more dilemmas and questions about selfdetermination, which confirms that they have more differentiated understandings about the phenomenon and consider it an important professional principle.

We emphasize that, despite the uncertainty of the concept of adulthood, assistants consider persons with high support needs as valuable people. They talk about their relationships with deep emotional involvement and empathy. They think 
of them as persons who have rights and who should be treated as we would like to be treated in similar situations.

In our work, we also assumed that in the context of group homes the key element in expanding the range of possibilities for self-determination is a complex assessment of personal preferences. To that end, we made use of the biographical approach. Through the method of biography, it is possible to map the subjectively relevant areas of self-determination. During the joint work, it has been proven that through the complex assessment of persons with high support needs and the support team and through the mobilization of their resources, the extension of self-determination is possible. Our research process has shown that workers are not familiar with the persons they are supporting due to fluctuation and the pressures of great workload.

Without changing the existing financial conditions and institutional structures, small elements of everyday processes have been developed to facilitate the change from the institutional culture to the paradigm of supported living services. In doing so, it was crucial to improve the frequency and quality of communication among different actors and to increase their involvement through individual time and attention.

The fact that parents and siblings are more likely to opt for full protection does not make the cooperation easier between them and other support personnel. Although staff members are typically more open to support freedom, they are afraid of responsibility. Facilitating the work of assistants is thus about finding a balance between restriction, responsibility, and self-determination.

\section{References}

Barnes, C. (1992). Qualitative Research: Valuable or Irrelevant? Disability, Handicap \& Society, 7(2), 115-124. https://doi.org/10.1080/02674649266780151

Barnes, C. (1996). Disability and the Myth of the Independent Researcher. Disability \& Society, 11(1), 107-110. https://doi.org/10.1080/09687599650023362

Bass L. (2004). SZÜLJÖN MÁSIKAT?! - Súlyosan-halmozottan fogyatékos gyermeket nevelő családok életkörülményei Magyarországon. In Bass L. (ed.). Jelentés a súlyosanhalmozottan fogyatékos embereket nevelö családok életkörülményeiröl (pp. 54-91). Budapest: Kézenfogva Alapítvány.

Beamer, S. \& Brookes, M. (2001). Making Decisions: Best Practice and new ideas for supporting people with high support needs to make decisions. London: Values into Action.

Bigby, C., Clement, T., Mansell, J. \& Beadle-Brown, J. (2009). "It's pretty hard with our ones, they can't talk, the more able bodied can participate": staff attitudes about the applicability of disability policies to people with severe and profound intellectual disabilities. Journal of Intellectual Disability Research, 53(4), 363-376. https://doi.org/10.1111/j.13652788.2009.01154.x

Corbin, J. \& Strauss, A. (2015). A kvalitatív kutatás alapjai. Budapest: L' Harmattan.

Dederich, M. (2008). Der Mensch als Ausgeschlossener. In Fornefeld, B. (ed.). Menschen mit Komplexer Behinderung. Selbstverständnis und Aufgaben der Behindertenpädagogik (pp. 31-49). München: Ernst Reinhardt.

Emerson, E., Hastings, R. \& McGill, P. (1994). Values, attitudes and service ideology. In Emerson, E., McGill, P. \& Mansell, Jim (eds). Severe Learning Disabilities and Challenging Behaviours (pp. 155-172). London: Chapman and Hall. https://doi.org/10.1007/978-14899-2961-7

Evans, S. (2010). Elfelejtett bünök. a holokauszt és a fogyatékossággal élő emberek. Budapest: ELTE Bárczi Gusztáv Gyógypedagógiai Kar \& ELTE Eötvös Kiadó.

Fischer, D. \& Bosse, D. (2010). Das Tagebuch als Lern-und Forschungsinstrument. In Friebertshäuser, B., Langer, A. \& Prengel, A. (eds). Handbuch Qualitative Forschungsmethoden in der Erziehungswissenschaft (pp. 871-886). 3. Auflage. Weinheim \& München: Juventa. 
Fornefeld, B. (2008). Verantwortung für Menschen mit Behinderungen im Wandel der Zeit. In Fornefeld, B. (ed.). Menschen mit Komplexer Behinderung. Selbstverständnis und Aufgaben der Behindertenpädagogik (pp. 14-30). München: Ernst Reinhardt.

Friebertshäuser, B. \& Panagiotopoulou, A. (2010). Ethnographische Feldforschung. In Friebertshäuser, B., Langer, A. \& Prengel, A. (eds). Handbuch Qualitative Forschungsmethoden in der Erziehungswissenschaft (pp. 301-322). 3. Auflage Weinheim \& München: Juventa.

Galambos É., Papp Z. \& Verdes T. (2003). A minőség problémája a felnőtt értelmi fogyatékosok lakhatást nyújtó szociális ellátásában. TDK-dolgozat. In Könczei György (ed.). (2009a). A súlyos és halmozott fogyatékossággal élő emberek helyzete Magyarországon. Tanulmánykötet (pp. 155-198). Első rész. Fogyatékosságtudományi tanulmányok VI. http://mek.oszk.hu/09500/09511/09511.pdf [Accessed: 01. 09. 2017.]

Glaser, B. C. \& Strauss, A. L. (2006). The Discovery of Grounded Theory. Strategies for Qualitative Research. New Brunswick, London: Aldine Transaction.

Haeberlin, U. (1996). Selbstständigkeit und Selbstbestimmung für alle - pädagogische Vision und gesellschaftliche Realität. Zeitschrift für Heilpädagogik, 47(12), 486-492.

Hellzen, O., Asplund, K., Sandman, P-O. \& Norberg, A. (2004). The meaning of caring as described by nurses caring for a person who acts provokingly: an interview study. Scandinavian Journal of Caring Sciences, 18(1), 3-11. https://doi.org/10.1111/j.14716712.2004.00256.x

Kozma Á. (2008). Az intézetben élö értelmi fogyatékos emberek élethelyzete. In Bass L. (ed.). Amit tudunk és amit nem... az értelmi fogyatékos emberek helyzetéről Magyarországon (pp. 157-177). Budapest: Kézenfogva Alapítvány,

Márkus E. (2005). Súlyosan-halmozottan fogyatékos gyermekek nevelésének elméleti és gyakorlati problémái. Doktori disszertáció. Budapest: Eötvös Loránd Tudományegyetem.

Martin, J. E., Woods, Lee L., Sylvester, L. \& Gardner, J. E. (2005). A Challenge to SelfDetermination: Disagreement between the Vocational Choices Made by Individuals with Severe Disabilities and Their Caregivers. Research and Practice for Persons with Severe Disabilities, 30(3), 147-153. https://doi.org/10.2511/rpsd.30.3.147

Mayring, P. \& Gläser-Zikuda, M. (eds) (2008). Die Praxis der Qualitativen Inhaltsanalyse. 2. Auflage. Weinheim \& Basel: Beltz Verlag.

Mayring, P. (2015). Qualitative Inhaltsanalayse. Grundlagen und Techniken. 12. überarbeitete Auflage. Weinheim \& Basel: Beltz Verlag.

Quinn, G. (2013). Liberation, Cloaking Devices and the Law. Or a personal reflection on the Law and Theology of Article 12 of the UN CRPD. Lecture, 13.11.2013. Budapest: Fogyatékos Emberek Szervezeteinek Tanácsa.

Seifert, M. (2006). Lebensqualität von Menschen mit schweren Behinderungen. Forschungsmethodischer Zugang und Forschungsergebnisse. Zeitschrift für Inklusion-online, (2). http://bidok.uibk.ac.at/library/inkl-02-06-seifert-lebensqualitaet.html [Accessed: 01. 09. 2017.]

Shalock, R. L., Verdugo, M. A., Jenaro, Ch., Wang, M., Wehmeyer, M., Jiancheng, X. \& Lachapelle, Y. (2005). Cross-Cultural Study of Quality of Life Indicators. American Journal on Mental Retardation, 110(49), 298-311. https://doi.org/10.1352/0895-8017(2005)110[298:CSOQ $\mathrm{OL}$ 2.0.CO;2

Theunissen, G. (2012). Lebensweltbezogene Behindertenarbeit und Sozialraumorientierung. Eine Einführung in die Praxis. Freiburg: Lambertus.

Verdes T. (2009). „A ház az intézet tulajdona”. a totális intézmények lebontásáról, humanizálásáról és modernizálásáról. Esély, 20(4), 92-114. http://www.esely.org/ kiadvanyok/2009_4/05verdes.pdf [Accessed: 01. 09. 2017.]

Walker, H. M., Calkins, C., Wehmeyer, M. L., Walker, L., Bacon, A., Palmer, S. B., Jesien, G. S., Nygren, M. A., Heller, T., Gotto, G. S., Abery, B. H. \& Johnson, D. R. (2011). A SocialEcological Approach to Promote Self-Determination. Exceptionality: A Special Education Journal, 19(1), 6-18. https://doi.org/10.1080/09362835.2011.537220

Wehmeyer, M. L., Agran, M. \& Hughes, C. (2000). A National Survey of Teachers' Promotion of Self-Determination and Student-Directed Learning. The Journal of Special Education, 34(2), 58-68. https://doi.org/10.1177/002246690003400201

Wehmeyer, M. L. (2005). Self-determination and Individuals with Severe Disabilities: Reexamining Meanings and Misinterpretations. Research and Practice for Persons with Severe Disabilities, 30(3), 113-120. https://doi.org/10.2511/rpsd.30.3.113

Weigand, G. (2009). Einleitung der Herausgeberin. In Weigand, G. (ed.). Die Praxis des Tagebuchs. Beobachtung- Dokumentation- Reflexion (pp. 7-32). Münster: Waxmann Verlag.

Weingärtner, C. (2009). Schwer geistig behindert und selbstbestimmt. Freiburg: Lambertus. 
Young, I. M. (1990). Az elnyomás öt arca (transl. Harasztosi P. \& Kacsuk Z.). http://www. kallaierno.hu/data/files/az_elnyomas_arca_YWop5A.pdf [Accessed: 01. 09. 2017.] [Original: Young, I. M. Justice and the politics of difference. Chapter 2: Five Faces of Oppression (pp. 39-65). Princeton: Princeton University Press.

Zászkaliczky P. (ed.) (1998). A függőségtől az autonómiáig. Helyzetértékelés és jövőkép a kiscsoportos lakóotthonokról. Budapest: Kézenfogva Alapítvány.

Zászkaliczky P. (2014). a gyógypedagógia: A fogyatékosság tudománya. Fogyatékosság és Társadalom, (5-6), 73-85. 